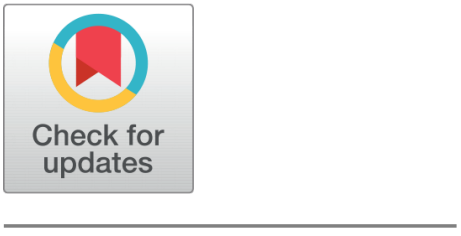

OPEN ACCESS

Received: 12.06 .2021

Accepted: 20.09.2021

Published: 11.10 .2021

Citation: Sivamani S, Manimaran DR, Banupriya A, Prathap N, Vasu G, Kanakasabai P (2021) A Comprehensive Review on Liquid-Liquid Extraction Based Systems in Treatment of Textile Wastewater. Indian Journal of Science and Technology 14(33): 2646-2662. https://doi.org/ 10.17485/IJST/v14i33.1076

* Corresponding author. drmanichem@gmail.com

Funding: None

Competing Interests: None

Copyright: () 2021 Sivamani et al. This is an open access article distributed under the terms of the Creative Commons Attribution License, which permits unrestricted use, distribution, and reproduction in any medium, provided the original author and source are credited.

Published By Indian Society for Education and Environment (iSee)

ISSN

Print: 0974-6846

Electronic: 0974-5645

\section{A Comprehensive Review on Liquid-Liquid Extraction Based Systems in Treatment of Textile Wastewater}

\author{
S Sivamani ${ }^{1}$, D R Manimaran²*, A Banupriya ${ }^{2}$, N Prathap², G Vasu1', \\ P Kanakasabai ${ }^{1}$ \\ 1 Chemical Engineering Section, Engineering Department, University of Technology and \\ Applied Sciences, Salalah, Oman \\ 2 Department of Biotechnology, Kumaraguru College of Technology, Coimbatore, India
}

\section{Abstract}

Objectives: To present an overview on various extraction systems used in treatment of textile wastewater. Methods: Google Scholar database was used to collect literature on liquid-liquid extraction systems in treatment of textile wastewater between 2000 and 2021. Findings: Even though a variety of methods are available for treatment of textile wastewater, certain methods remain neglected without much attention. One such method is liquid-liquid extraction-based systems. Hence, the manuscript presented an overview on applications of liquid-liquid extraction systems in treatment of textile wastewater. Novelty: Wastewater treatment is most important in today's life because of excess urbanization and industrialization. In developing countries, tonnes of wastewater is discharged without prior treatment. Hence, liquidliquid extraction could be a novel method for treatment of textile wastewater.

Keywords: Wastewater; Liquidliquid extraction; Liquid membrane; Cloud point extraction; Reverse micellar extraction

\section{Introduction}

After the advent of chemical processing industries on earth, they serve as the highest polluter of clean water. The major chemical industries that create water pollution include textile, leather, electroplating, etc. ${ }^{(1)}$. The pollution load on the liquid effluent increases with subsequent steps of chemical processing, where the contribution of one single step amounts to about $8-20 \%$ of the total pollution load due to incomplete exhaustion of the pollutant ${ }^{(2)}$.

The water consumption in chemical processing operation varies from 50-300 L for every $\mathrm{kg}$ of the processing goods ${ }^{(3)}$. The conventional wastewater treatment methods include oxidation, adsorption, extraction, electrolysis, membrane separation, etc. The methods have their own merits and demerits ${ }^{(4)}$.

Table 1 shows the advantages and disadvantages of different dye removal methods. When compared with the methods available in the literature, the solvent extraction method has advantages in terms of efficiency and simplicity of the process design ${ }^{(5)}$. The recovery of the solvent and reuse after its removal is related to the 
economic viability of the process ${ }^{(6)}$.

Table 1. Advantages and disadvantages of methods for wastewater treatment

\begin{tabular}{|c|c|c|c|}
\hline Physical/chemical methods & Advantages & Disadvantages & Reference \\
\hline Fenton's reagent & $\begin{array}{l}\text { Effective decolourization of both soluble and insol- } \\
\text { uble dyes }\end{array}$ & Sludge generation due to $\mathrm{Fe}^{2+}$ used & (7) \\
\hline Ozonation & Applied in gaseous state no alternative of volume & Short half-life (20 min) of ozone & (8) \\
\hline Photocatalysis & No sludge production & Formation of by products & (9) \\
\hline Electrochemical treatment & Degraded compounds are non-hazardous & High cost & (10) \\
\hline Ion exchange & Regeneration, no adsorbent loss & Not effective all types of dyes & (11) \\
\hline Biological processes & $\begin{array}{l}\text { Environmentally friendly, public acceptance, eco- } \\
\text { nomically attractive }\end{array}$ & $\begin{array}{l}\text { Slow process, needs adequate nutrients, } \\
\text { narrow operating temperature range }\end{array}$ & (12) \\
\hline $\begin{array}{l}\text { Advanced chemical oxida- } \\
\text { tion }\end{array}$ & Non-hazardous end products & High cost & (13) \\
\hline $\begin{array}{l}\text { Coagulation and precipita- } \\
\text { tion }\end{array}$ & Effective for all dyes & High sludge production, high cost & (14) \\
\hline Nanofiltration & $\begin{array}{l}\text { High effluent quality, removes all dye, easy to scale- } \\
\text { up }\end{array}$ & $\begin{array}{l}\text { High investment costs, membrane- } \\
\text { types and fouling, effluent must } \\
\text { betreated }\end{array}$ & (15) \\
\hline Adsorption & $\begin{array}{l}\text { Low cost, no regeneration needed, dye-adsorbed } \\
\text { materials can be used as substrates in solid state } \\
\text { fermentation }\end{array}$ & $\begin{array}{l}\text { Some adsorbents have low surface } \\
\text { area, possible side reactions loss of } \\
\text { adsorbents, performance dependents } \\
\text { on wastewater characteristics }\end{array}$ & (16) \\
\hline $\begin{array}{l}\text { Liquid-liquid or solvent } \\
\text { extraction }\end{array}$ & $\begin{array}{l}\text { Low cost, low energy consumption, variety of } \\
\text { solvents, available easy to scale-up }\end{array}$ & $\begin{array}{l}\text { Emulsification may occur, effluent } \\
\text { must be treated }\end{array}$ & (17) \\
\hline $\begin{array}{l}\text { Supported liquid mem- } \\
\text { brane }\end{array}$ & $\begin{array}{l}\text { Minimal loss of extractant, simple operation, less } \\
\text { energy wastage, ease of scale-up, cheap }\end{array}$ & Emulsification may occur & (18) \\
\hline Reverse micellar extraction & $\begin{array}{l}\text { Efficient recovery, continuous operation, high } \\
\text { capacity, cost effective, and recyclability }\end{array}$ & $\begin{array}{l}\text { Slow rate of back extraction and possi- } \\
\text { bility of structural changes of solute }\end{array}$ & (19) \\
\hline Cloud point extraction & $\begin{array}{l}\text { Low cost, Speedy recovery, Higher efficiency, less } \\
\text { toxic and safe }\end{array}$ & $\begin{array}{l}\text { Time-consuming and laborious for } \\
\text { large sample volume }\end{array}$ & $(20)$ \\
\hline Bulk liquid membrane & $\begin{array}{l}\text { Simple and cheap to construct over other types of } \\
\text { liquid membranes }\end{array}$ & $\begin{array}{l}\text { Expensive, less stable and not suitable } \\
\text { for large scale }\end{array}$ & $(21)$ \\
\hline Emulsion liquid membrane & High flux, High interfacial area and High recovery & $\begin{array}{l}\text { Emulsion stability and feed and water } \\
\text { occlusion, second-dary emulsification }\end{array}$ & $(22)$ \\
\hline
\end{tabular}

Among various methods that have been used for the removal of dyes from aqueous solution, physical methods such as adsorption, coagulation, photocatalytic degradation, ozone treatment, electro Fenton's, and hypochlorite treatment are nondestructive and merely transfer the pollutants from one medium to another thus giving secondary treatment. But liquid-liquid extraction has been chosen because it gives high throughput, ease of operation, scale-up, and high purification ${ }^{(17)}$. Chang $(2020)$ presented a review on sustainable wastewater treatment using extraction systems ${ }^{(23)}$. But the study is limited to green organic solvents. Hence, the present review covers the application of solvent extraction systems in treatment of textile wastewater.

\section{Methodology}

Google Scholar database was used to collect literature on liquid-liquid extraction systems in treatment of textile wastewater between 2000 and 2021.

\section{Extraction systems used in wastewater treatment}

\section{Liquid-liquid Extraction}

Liquid-liquid extraction (LLE) is a unit operation that involves the transfer of a solute from solution to the extracting solvent ${ }^{(24)}$. A typical liquid-liquid extraction system in chemical process industries consists of feed solution containing solute (C) and original solvent $(\mathrm{A})$ and extracting solvent $(\mathrm{B})$. When the feed solution $(\mathrm{A}-\mathrm{C})$ is mixed with extracting solvent, based on the solubility of solute $\mathrm{C}$ in extracting solvent $\mathrm{B}$, solute diffuses in solvent $\mathrm{B}$ so that separation of solute from feed solution occurs. When feed and extracting solvent are mixed, proper mixing should be provided for effective mass transfer between solute and 
solvent B. As a result, two distinct phases form - extract and raffinate. The extract phase, also called as solvent-rich phase, contains a ternary mixture of A-B-C with the majority of $\mathrm{C}$ and $\mathrm{B}$. Raffinate phase, also called as solvent lean phase, contains a ternary mixture of A-B-C with the majority of A. Based on the density difference between extract and raffinate phases, separation occurs. The extract phase is further separated by using distillation or any other similar unit operation to separate solute and extracting solvent ${ }^{(25,26)}$. Extracting solvent is recycled for its use in process industries. Sometimes, a mixture of solvents is used as extracting solvent, and such an extraction system is called double-solvent or fractional extraction ${ }^{(27-29)}$.

Liquid-liquid equilibrium is illustrated in the triangular diagram as the system involves a ternary mixture. After mixing feed and extracting solvent, the ternary mixture reaches equilibrium after some time ${ }^{(30)}$. The triangular diagram represents the liquid-liquid equilibrium between extract and raffinate phases. Selectivity and distribution coefficient is used to describe the liquid-liquid equilibrium. Selectivity is defined as the ratio of mass fraction of $\mathrm{C}$ to $\mathrm{A}$ in the extract to the mass fraction of $\mathrm{C}$ to $\mathrm{A}$ in the raffinate. Separation by extraction is not possible when selectivity is closer or equal to unity. The distribution coefficient is defined as the ratio between the concentration of solute $\mathrm{C}$ in extract and raffinate phases. The distribution coefficient is also far from one for better separation by extraction ${ }^{(31)}$. The selection of extracting solvent is an important criterion in liquid-liquid extraction. They are selectivity, distribution coefficient, insolubility in original solvent, recoverability, reusability, cheap, nontoxic, density, interfacial tension, inertness, viscosity, vapour pressure, freezing point, non-flammable, etc. ${ }^{(32)}$.

Valley et al., (2019) explored a new approach of wastewater treatment using macroionic coacervate complexes formed with zwitterionic polyampholytes and anionic inorganic polyoxometalate (POM) nanoclusters to extract methylene blue (MB) dye as well as other cationic industrial dyes from model wastewater ${ }^{(33)}$. Effluent wastewater containing dyes from textile, paint, and various other industrial wastes have long posed environmental damage. Functional nanomaterials offer new opportunities to treat these effluent wastes in an unprecedentedly rapid and efficient fashion due to their large surface area-to-volume ratio. Biphasic organic-inorganic macroion complexes are designed to produce a small volume of coacervate adsorbents of high density and viscoelasticity, in contrast to a large volume of supernatant solution for rapid and efficient dye removal. The efficiency of coacervate extraction is characterized by the adsorption isotherm and maximum MB uptake capacity against the concentrations of polyampholyte, POM, and $\mathrm{LiCl}$ salt using UV-vis spectrophotometry to optimize the coacervate formation conditions. Our macroionic coacervate complexes could reach nearly $99 \%$ removal efficiency for the model wastewater samples of varied $\mathrm{MB}$ concentration in $<1 \mathrm{~min}$. The extraction capacity up to $\sim 400 \mathrm{mg} / \mathrm{g}$ far surpasses the dye extraction efficiency of widely used activated carbon adsorbents. We also explore the regeneration of coacervate complexes containing high concentration of extracted MB by a simple Fenton oxidation process to bleach coacervate complexes for repeated POM usage, which shows similar MB extraction efficiency after regeneration. Hence, coacervate extraction based upon spontaneous liquidliquid separating complexation between polyzwitterions and POMs is demonstrated as a rapid, efficient, and sustainable method for industrial dye wastewater treatment. In perspective, coacervate extraction could advantageously possess dual processing options in separation industry through either membrane fabrication or use directly in mixer-settlers.

Ferreira et al., (2014) proposed to remove dyes from aqueous discharges using ionic liquid (IL)-based aqueous two-phase systems (ATPS) aiming at developing more benign methodologies than those studied hitherto ${ }^{(34)}$. The textiles manufacturing is one of the core industries which discharges a heavy load of chemicals during the dying process. As a result, the release of large contents of dyes through aqueous effluents leads to both environmental and economic concerns. A detailed study on the partition coefficients and extraction efficiencies of a set of textile dyes (chloranilic acid, indigo blue and sudan III) using ATPS composed of ILs (phosphonium- and imidazolium-based) and an inorganic (aluminium sulphate) or organic salt (potassium citrate) is here addressed. The gathered data allow the evaluation of the IL chemical structure, the nature of the salt, as well as the $\mathrm{pH}$ of the aqueous medium. The results obtained reveal that a proper selection of the IL and salt can lead to the complete extraction of the three dyes to the IL-rich phase in a single-step procedure. Moreover, the dyes recovery to further allow the reuse of the IL-rich phase is also described. This new approach, using hydrophilic ILs, is consequently more environmentally friendly and could be envisaged as a promising process for reducing the pollution of wastewaters.

Othman et al., (2014) studied the removal of remazol red 3BS from simulated textile wastewater using tetrabutyl ammonium bromide (TBAB) at room temperature with total operation time of 18 hours ${ }^{(35)}$. Dyes caused serious environmental pollution and health problem in many ways. Many dyes have toxic effects on aquatic life and also on humans. Liquid-liquid extraction process is one of the alternatives for dye removal from wastewater. Several parameters have been studied such as $\mathrm{pH}$, diluents, initial dye concentration, extractant concentration and stripping agents toward the extraction process of the dye. The results show only small effects of $\mathrm{pH}$ on the extraction percentage. The best diluent for the extraction is dichloromethane with the percentage of $98 \%$. The percentage of extraction is maximum $(97 \%)$ at $0.07 \mathrm{M}$ of TBAB concentration with the distribution ratio of $\mathrm{D}=34.65$. Salicylic acid in $\mathrm{Na}_{2} \mathrm{CO}_{3}$ with the ratio of $1: 2$ gives the highest percentage of stripping process. It shows a good performance for liquid-liquid extraction of remazol red 3BS for both removal and recovery processes. 
El-Ashtoukhy and Fouad (2015) investigated the extraction of methylene blue dye from aqueous solution using sodium dodecylbenzenesulfonate as an extractant ${ }^{(36)}$. The various diluents used were benzene, toluene, xylene and dichloroethane. Dichloroethane was found to be the most effective diluent for the extraction of the dye. The investigated parameters, governing the extraction of the dye, were equilibrium time, $\mathrm{pH}$ of the dye solution, extractant concentration, dye concentration, temperature and aqueous to organic phase ratio. The dye was totally extracted at the optimum conditions. The dye loaded in the organic phase was stripped using various types of acids as stripping agent; complete recovery of the dye was achieved using $0.5 \mathrm{M}$ thiourea in $1 \mathrm{M} \mathrm{HCl}$.

Soniya and Muthuraman (2015a) compared liquid-liquid extraction and bulk liquid membrane (BLM) methods on the removal and recovery of methylene blue dye from textile wastewater by using salicylic acid in benzene ${ }^{(37)}$. First, the liquidliquid extraction of methylene blue dye was investigated. The parameters examined in this research were the effect of diluents, effect of $\mathrm{pH}$, effect of extractant concentration, effect of dye concentration and the suitable stripping agent. Second, taking into consideration the obtained results, the transport of methylene blue dye across a bulk liquid membrane was studied. All the mentioned parameters applied in BLM technique and results are discussed.

Soniya and Muthuraman (2015b) aimed at the removal and recovery of methylene blue (MB) from wastewater ${ }^{(38)}$. MB is one of the most commonly used substances for dyeing cotton, wood, and silk. Though MB is not strongly hazardous, it can cause some harmful effects where acute exposure to MB may cause increased heart rate, vomiting, shock, cyanosis, jaundice and quadriplegia and tissue necrosis in human. So, we selected the MB for solvent/liquid-liquid extraction study. MB is the cationic dye, so it requires an anionic carrier for extraction purpose. Salicylic acid acts as an anionic carrier in this study. Removal of MB using salicylic acid in benzene was studied. The efficiency of dye extraction increased with decreasing dye concentration. The extracted dye in the organic phase can be back-extracted into $1 \mathrm{M}$ oxalic acid solutions. The experimental parameters examined were salicylic acid concentration, effects of diluents, effect of $\mathrm{pH}$, effect of initial dye concentration, effect of equilibrium time, aqueous to organic phase ratio, and various stripping agents. Real effluent was also studied under optimized condition and satisfactory result has been found.

Elumalai and Muthuraman (2018) investigated the removal and recovery of cationic dye namely methyl violet (MV) from aqueous solution by liquid-liquid extraction (LLE) ${ }^{(39)}$. Toluic acid demonstrated to be a very effective extractant for selective extraction of methyl violet from aqueous solution. The various diluents used were benzene, xylene hexane, toluene, kerosene. Among them, xylene was found to be the most effective diluent for extraction of methyl violet dye. The maximum extraction efficiency (99.0\%) was obtained at $\mathrm{pH} 12.0 \pm 0.1$. The other influencing parameters were also examined: effect of $\mathrm{pH}$ in feed phase, toluic acid concentration in organic phase, effect of diluents, acid concentration in strip phase and stripping phase ratio. The extracted dye has been successfully stripped by $0.5 \mathrm{~N} \mathrm{HCl}$. Real effluent was also extracted and found to give satisfactory result.

Muthuraman et al., (2012) extracted Cibacron Red FN-R from synthetic dye solution using tetra butyl ammonium bromide (TBAB) as an extractant ${ }^{(40)}$. Diluents such as benzene, hexane, toluene, carbon tetrachloride, chloroform, and dichloromethane were used for extraction. Studies revealed that dichloromethane to be the most effective diluent for the extraction of Cibacron Red FN-R dye. The effect of different parameters such as dye concentration, extractant concentration, aqueous $\mathrm{pH}$, equilibrium time, aqueous to organic phase ratio, nature of stripping reagent, stripping reagent concentration, stripping phase ratio, stripping contact time, and nature of diluents was examined under optimized conditions. The percentage of Cibacron Red FN-R extracted was found to be nearly 99.2\%. The extracted dye in the organic phase can be back extracted into an aqueous nitric acid solution.

Muthuraman and Teng (2009) conducted a laboratory study on the liquid-liquid extraction system that was carried out for the removal and recovery of Methyl red from aqueous solutions using Xylene as an extractant ${ }^{(17)}$. When studies had been carried out in varying concentrations of Methyl Red, results showed that the efficiency of dye extraction increased with increasing time of extraction. The distribution ratio is reasonably high $(\mathrm{D}=49)$ even in the presence of inorganic salts. Extracted dye in the organic phase has been stripped into Sodium hydroxide solution. The organic solvent is used for the re-extraction of the dye from an aqueous solution.

Muthuraman (2011) explored the extractive removal of cationic dyes namely Astryl Blue BG and Astryl Golden Yellow from aqueous solutions using salicylic acid dissolved in toluene ${ }^{(41)}$. The efficiency of extraction was studied under various experimental conditions such as $\mathrm{pH}$ of the feed solution, concentration of stripping agent, extraction concentration, extraction time, temperature, initial dye concentration, and reusability of the solvent. About $93-98 \%$ of dyes were extracted under the optimized experimental conditions. The extracted dyes were quantitatively stripped with a sulphuric acid solution. The organic phase obtained after the stripping of dyes was washed with dilute sodium hydroxide solution to neutralize any sulphuric acid trapped or adhered to the solvent and then with distilled water. This solvent was reused in the succeeding extraction of dyes up to 5 times. When real industrial wastewater was tested under the optimized conditions, $92 \%$ of dye was extracted at $25^{\circ}$ C. Results show that the removal efficiency of dyes increased with increased extractant concentration. The removal efficiency 
remained unchanged when inorganic salts such as $\mathrm{NaCl}$ were present in the aqueous solution. If this technique is introduced in textile industries, it can be economic and environmentally friendly.

Muthuraman and Palanivelu (2005) demonstrated tetrabutylammonium bromide (TBAB) to be a very effective reagent for selective extraction of textile anionic dyes from aqueous solution ${ }^{(42)}$. The solution of TBAB in methylene chloride can extract $98 \%$ of $50 \mathrm{mg} / \mathrm{l}$ concentration of dye solution. A high distribution ratio is observed $(\mathrm{D}=49.0)$ even in the presence of excess chloride and sulphate ions. Extracted dye in the organic phase can be back extracted with excess salicylic acid and sodium carbonate solution. After salicylic acid and sodium carbonate stripping and water, washing has been done, the organic layer of TBAB becomes regenerated and it can be recycled for further extraction. The stripped solution on acidification precipitated salicylic acid and the dye is removed. Parameters such as the effect of $\mathrm{pH}$, the nature of the solvent, the effect of surfactant concentration, the effect of equilibration time, the effect of salt concentration, the effect of stripping reagents, the reusability of solvent are also studied.

Muthuraman and Teng (2010) studied the solvent extraction of Methyl Violet from aqueous acidic solutions with extractant salicylic acid in xylene. the $\mathrm{pH}$ of the aqueous feed phase is adjusted using inorganic acids such as hydrochloric acid ( $\mathrm{HCl}$ ), sulphuric acid $\left(\mathrm{H}_{2} \mathrm{SO}_{4}\right)$, and nitric acid $\left(\mathrm{HNO}_{3}\right)^{(43)}$. At $\mathrm{pH}=6.0, \mathrm{HCl}$ was shown to give higher efficiency of extraction and higher distribution coefficient than $\mathrm{H}_{2} \mathrm{SO}_{4}$ and $\mathrm{HNO}_{3}$. The presence of salts such as sodium sulphate in the feed phase decreased the extraction efficiency. The extracted dye was stripped into an aqueous acetic acid solution. The stripping efficiency increased with increasing acetic acid concentration in the strip solution. Stripping efficiency was $99 \%$ and under optimized conditions, industrial wastewater was tested, and the results were found to be satisfactory.

Muthuraman et al., (2009) explored the Liquid-liquid extraction of Methylene Blue from industrial wastewater using benzoic acid as an extractant in xylene at $27^{\circ} \mathrm{C}^{(44)}$. From the experimental studies, it was found that the extraction of the dye increased with increasing extractant concentration. The extraction abilities have been studied on benzoic acid concentration in various ranges. The distribution ratio was found to be reasonably high $(\mathrm{D}=49.5)$ even in the presence of inorganic salts. Extraction under optimal conditions of extractant concentration of $29 \mathrm{mM}, \mathrm{pH}$ of 11 , and temperature of $30{ }^{\circ} \mathrm{C}$ was $90-99 \%$ after 15 min of phase separation, irrespective of the concentration of the dye. Back extraction in sulphuric acid is done after the dye is extracted in the organic phase. Depending on the concentration of the initial feed solution, the resultant recovered organic phase can be reused in the succeeding extraction of dye with the yield ranging from 99 to $87 \%$ after reusing it about 15 times. The experimental parameters that are examined are benzoic acid concentration, the effect of equilibration time, various stripping agents, aqueous to organic phase ratio in extraction, organic to aqueous phase ratio in stripping, and reusability of solvent.

Muthuraman and Palanivelu (2006) conducted a laboratory study on the transport of textile dyes in vegetable oils-based supported liquid membrane (SLM) ${ }^{(45)}$. The SLM system has been investigated for removal and recovery of textile dyes from the aqueous solution using renewable, non-toxic, natural vegetable oils such as coconut, castor, sunflower, olive, gingelly, groundnut, palm, and mustard oils, never used before as liquid membrane. Only castor oil has not transported the dye across the membrane. A flat polypropylene (PP) sheet supported Teflon membrane impregnated with vegetable oils has been tested for the transport of a cationic dye, Astryl Golden Yellow. The fundamental parameters influencing the transport of dyes such as $\mathrm{pH}$ in the feed solution, $\mathrm{H}_{2} \mathrm{SO}_{4}$ concentration in the strip solution and different types of oils, stirring speed, initial dye concentrations have been determined and the stability of the membrane was checked.

Muthuraman and Palanivelu (2004) conducted a laboratory study on Liquid-liquid extraction of a low salt textile dye namely Golden Yellow LS, an anionic type and investigated for its removal and recovery from aqueous solution using n-tributyl phosphate (TBP) and hexane ${ }^{(46)}$. The dye was extracted into a solvent mixture from an acidic medium. The extracted dye can be recovered by stripping it into an alkali solution. The solvent can be reused after stripping the dye. The influence of parameters such as dye composition, $\mathrm{pH}$, solvent composition, salt concentration, equilibration time, aqueous/organic volume ratio, percentage removal, and recovery of dye was studied. Extraction of Golden Yellow LS was found to be 68-95\% with an increase in time, solvent capacity, and equilibration capacity.

Othman et al., (2011) explored that the liquid-liquid extraction method to recover the Black B Dye using Thiodianiline (TDA) in kerosene at favourable conditions ${ }^{(47)}$. Decolourization of wastewater is very important before discharge. The main parameters governing the extraction behaviour of Black B dye have been investigated such as $\mathrm{pH}$ of the source phase, extractant concentration, dye concentration, and stripping agent. The experiment was carried out in a batch process. Almost $98 \%$ was extracted using $0.04 \mathrm{M}$ TDA and $\mathrm{pH}$ of the source phase. The extraction of dye decreased as the $\mathrm{pH}$ of the solution increased.

Tuteja and Sharma (2009) founded that re-use of recovered dye is possible with almost similar properties by suitable makeup of the dye bath ${ }^{(48)}$. Textile effluent is the major source of pollution and a threat to mankind. Most of the dyes used are synthetic with bulk carbon content. Reactive (Triazine) dyes are preferred for the dyeing of cellulosic fabrics because of their wide shade range, easy application, and better colour fastness properties. But the drawback with these dyes is their great affinity for water. Due to this large amount (approx. 30\%) of the dye remains unreacted and discharged into the effluent. This increases the cost 
of dyeing and pollution load. In the present work, recovery, and re-use of untreated dyes from the textile effluent are studied by a solvent extraction process using surfactants. Studies are carried out with Reactive Blue 171 from the triazine class of reactive dye having a molecular weight of 1418.9. The solvent taken for the studies is iso-amyl alcohol as the lower alcohols are soluble in water. The process involves two steps: the first step is the removal of unreacted dye from textile effluent i.e., aqueous phase into solvent phase using reverse micelles of cationic surfactant i.e., Hexadecyl trimethyl ammonium bromide. In the second step, dye is backward extracted into the aqueous phase from the solvent phase using anionic surfactant i.e., Sodium dodecylbenzene sulfonate. Recovered dye is re-used to dye the fabric and the shade, colour fastness, and strength properties of the fabric are compared with the fabric dyed with native dyes.

Elumalai et al., (2013) worked on the recovery of dye from textile effluents using phenol as an extractant ${ }^{(49)}$. The extraction behaviour of cationic dye namely Rhodamine B (RB) from acidic solution has been investigated using phenol in xylene as a carrier. The maximum extraction efficiency of $\mathrm{RB}$ from an aqueous solution was found to be $\mathrm{pH}$ 1.0. The extraction of dye increases with increasing phenol concentration in the organic phase. The other influencing parameters were also examined, the effect of $\mathrm{pH}$ in the feed phase, phenol concentration in the organic phase, the effect of diluents, the effect of inorganic salts, acid concentration in strip phase, and stripping phase ratio. Real effluent was also extracted and found to give satisfactory results.

$\mathrm{Xu}$ et al., (2006) proposed that solvent extraction is an effective way to treat and recover phenolic compounds from the high content phenolic wastewater ${ }^{(50)}$. This is because phenol is a common pollutant discharged from petroleum and petrochemical, coal conversion, and phenol-production industries. The experimental study on treating the wastewater containing phenol was carried out with QH-1 extractant (an amine mixture) and annular centrifugal contactors. High distribution ratio-108.6 was observed for the QH-1-phenol system. The mass transfer efficiency, E was observed at various conditions by changing the flow ratio, controlling rotor speed and total flow giving rise to the efficiency of the single-stage contactors more than $95 \%$ and extraction rate of the three-stage cascade more than $99 \%$. Under the experimental conditions, the stripping efficiency of the three-stage cascade was also more than $99 \%$.

Hu et al., (2005) experimentally designed and studied the treatment of strong acid dye wastewater by solvent extraction ${ }^{(51)}$. The studies involve removal of acid dye intermediates 1-diazo-2-naphthol-4-sulfonic acid by using solvent trialkyl amine $\mathrm{N}_{235}$ and treatment of raffinate by hydrogen peroxide catalytic oxidation. This is done because the dye wastewater containing aromatic series with sulpho-, nitro-, amino cyanogen or chloro-compounds, would badly pollute the environment. The optimum parameters were obtained by testing the extraction and stripping conditions. Kerosene was used as a diluent and a small quantity of modifier, iso-octanol was used to increase the efficiency of the extraction process. The recovery of dye intermediates can reach higher than $82-86 \%$ in a single-stage extraction. Multistage counter current extraction and stripping experiments were also carried out. The raffinate coming out after extraction is treated by hydrogen peroxide catalytic oxidation to remove the COD. After treatment, the solution was achromatic, and the COD of the effluent was below $100 \mathrm{mg} / \mathrm{l}$.

Vijayaraghavan et al., (2006) studied in detail azo dyes which are commonly used in leather and textile industries as they are quite versatile ${ }^{(52)}$. They found that however, they are neither totally utilized during the process, nor they are recovered at the end of the process. In fact, in the leather industries, about $10-15 \%$ of the dye is discharged with the effluent creating both environmental and economic issues. Hence there is a need to remove the residual dyes from the large volume of aqueous effluent. In the study, azo dyes employed in the leather industry have been successfully extracted into a neutral ionic liquid, with an extraction efficiency of $98 \%$, potentially providing a method of minimizing the pollution of wastewaters. The extraction of the dye into the ionic liquid also provides a potential analytical approach for the determination of these dyes.

Raghavarao et al., (2003) examined and suggested aqueous two-phase extraction (ATPE) as a liquid-liquid extraction technique employing two aqueous phases comprising either two polymers or a polymer and a salt ${ }^{(53)}$. In addition to the other advantages it offers, ATPE is gaining increasing popularity as an environmentally benign technique because (1) it does not employ volatile organic compounds as solvents, (2) it involves phase-forming polymers that rely on the structuring properties of liquid water not only for the formation of phase systems but also for solubilizing the otherwise relatively insoluble hydrophobic solutes, (3) it exploits the remarkable properties of polymers such as polyethylene glycols, polyvinyl pyrrolidone (PVP), etc. and (4) it makes use of phase-forming components which could be recovered and recycled to a limited degree. In some modified form, ATPE is finding application in environmental remediation. ATPE is discussed by considering case studies involving extraction of enzymes for waste treatment and recovery of valuable by-products from waste, extraction of useful components of plant origin, and extraction of natural colours. The scope of ATPE in the context of pollution prevention or application for environmental remediation is discussed. Advantages/limitations of ATPE are also discussed.

Yahya et al., (2008) studied and optimized the factors affecting the extraction of red dye by the molecularly imprinted polymer $(\mathrm{MIP})^{(54)}$. Selective polymeric extractants were prepared for preconcentration of Cibacron reactive red dye, a dye that is often applied with Cibacron reactive blue and Cibacron reactive yellow for dyeing of fabrics. The best extractant was fabricated (in chloroform) using methacrylic acid (as monomer), ethylene glycol dimethacrylate (as crosslinker), AIBN (as an initiator for 
polymerization), and red dye as template molecule, with a molar stoichiometric ratio of 8.0:40.0:2.5:0.63, respectively. The structure of the MIP was robust and resisted dissolution up to $260{ }^{\circ} \mathrm{C}$. Compared with the unimprinted polymer, the imprinted product has a large specific surface area which improved its adsorption capacity. The effect of imprinting was obvious from the adsorption capacity measured at $\mathrm{pH} 4$ for red dye (the imprinted molecule), which was increased from 24.0 to $79.3 \mathrm{mg} \mathrm{g}^{-1}$ after imprinting. Equilibrium adsorption studies revealed that the dye-imprinted-polymer enables efficient extraction of red dye even in the presence of blue and yellow dyes which have similar chemical natures to the red dye. The selectivity coefficients of red dye/dye were 13.9 and 17.1 relative to the yellow and blue dyes, respectively. The MIP was found to be effective for red dye preconcentration, with a preconcentration factor of 100, from tap water and treated textile wastewater. Under the optimized extraction conditions, red dye was selectively quantified in the presence of other competing dyes at a concentration of $20 \mu \mathrm{g}$ $\mathrm{L}^{-1}$ from different water systems with satisfactory recoveries $(91-95 \%)$ and $\mathrm{RSD}$ values $(\sim 5.0 \%)$.

Chen and Wei (2010) studied the separation of ionic dyes (methylene blue, neutral red, methyl orange, and acid orange) with 1-alkyl-3-methylimidazolium ionic liquids as the eluent additives using the Reversed-phase HPLC ${ }^{(55)}$. The addition of an ionic liquid to the eluent affects the resolution, peak shape, and reproducibility of the retention of ionic solutes. The use of ionic liquids as additives facilitates the separation of ionic dyes with a reversed-phase HPLC. Baseline-resolved separation of these dyes was achieved in $12 \mathrm{~min}$ when thermopile phase of acetonitrile-water (28:72, v/v) contained 0.3-2.0\% (v/v) [EMIM][BF4]. The detection limits for the four dyes ranged from 4.45 to $10.0 \mathrm{~g} / \mathrm{L}$ for an injection volume of $20 \mathrm{~L}$. The ionic liquid is an effective mobile phase additive for the separation of ionic dyes in reversed phase HPLC separation. Table 2 summarizes the liquid-liquid extraction for the removal of various dyes.

Table 2. Liquid-Liquid Extraction for the removal of dyes

\begin{tabular}{|c|c|c|c|c|c|}
\hline S. No. & Dye & Solvent & \% removal & Parameters studied & Reference \\
\hline 1 & $\begin{array}{l}\text { Cibacron Red } \\
\text { FN-R }\end{array}$ & $\begin{array}{l}\text { Extractant } \\
\text { Tetrabutylammonium } \\
\text { bromide/diluents- } \\
\text { benzene, hexane, } \\
\text { toluene, carbon tetra- } \\
\text { chloride, chloroform, } \\
\text { and dichloromethane. }\end{array}$ & $99.20 \%$ & $\begin{array}{l}\text { Aqueous } \mathrm{pH} \text {, extractant concentration, dye con- } \\
\text { centration, equilibration time, aqueous to organic } \\
\text { phase ratio, nature of stripping reagent, stripping } \\
\text { reagent concentration, stripping phase ratio, and } \\
\text { stripping contact time }\end{array}$ & $(40)$ \\
\hline 2 & $\begin{array}{l}\text { Astacryl Blue } \\
\text { BG and Astacryl } \\
\text { Golden Yellow }\end{array}$ & $\begin{array}{l}\text { Salicylic acid with } \\
\text { toluene }\end{array}$ & $93-98 \%$ & $\begin{array}{l}\mathrm{pH} \text { of the feed solution, the concentration of strip- } \\
\text { ping agent, extractant concentration, extraction } \\
\text { time, temperature, initial dye concentration, and } \\
\text { reusability of solvent }\end{array}$ & $(41)$ \\
\hline 3 & $\begin{array}{l}\text { Golden yel- } \\
\text { low, Cibacron } \\
\text { LSG-HC, Brown } \\
\text { ERN, Levafix } \\
\text { Red CA and } \\
\text { Levafix Scar- } \\
\text { let CA/ NaCl, } \\
\text { Na2So4 }\end{array}$ & $\begin{array}{l}\text { Extractant - } \\
\text { Tetrabutylammonium } \\
\text { bromide/diluent- } \\
\text { methylene chloride }\end{array}$ & $98 \%$ & $\begin{array}{l}\text { Aqueous } \mathrm{pH} \text {, extractant concentration, dye con- } \\
\text { centration, equilibration time, aqueous to organic } \\
\text { phase ratio, nature of stripping reagent, stripping } \\
\text { reagent concentration, stripping phase ratio, strip- } \\
\text { ping contact time, and reusability of solvent }\end{array}$ & (43) \\
\hline 4 & $\begin{array}{l}\text { Astacryl golden } \\
\text { yellow }\end{array}$ & $\begin{array}{l}\text { Vegetable } \\
\text { oils/polypropylene } \\
\text { (PP) supported Teflon } \\
\text { membrane }\end{array}$ & $<95 \%$ & $\begin{array}{l}\mathrm{pH} \text { in the feed solution, } \mathrm{H}_{2} \mathrm{SO}_{4} \text { concentration in } \\
\text { the strip solution and different type of oils, stirring } \\
\text { speed, initial dye concentrations }\end{array}$ & (44) \\
\hline 5 & Direct yellow & $\mathrm{NaCl} / \mathrm{AOT}$ & $98-99.9 \%$ & $\begin{array}{l}\text { Distribution co-efficient, } \mathrm{pH} \text {, Surfactant dose, } \\
\text { electrolyte concentration }\end{array}$ & (50) \\
\hline 6 & Eosin dye $/ \mathrm{NaCl}$ & Triton X-100 & $87.5-100 \%$ & $\begin{array}{l}\text { The concentration of feed mixture, temperature, } \\
\text { and salt concentration }\end{array}$ & (51) \\
\hline 7 & $\begin{array}{l}\text { Rhodamine } 6 \mathrm{G} \\
\text { (R6G) }\end{array}$ & Triton X-100 & & $\begin{array}{l}\mathrm{pH} \text {, the concentration of Triton } \mathrm{X}-100(\mathrm{TX}-100) \\
\text { and salts, equilibrium temperature, and incubation } \\
\text { time on the efficiency of the extraction of R6G. }\end{array}$ & (52) \\
\hline
\end{tabular}

Many conventional methods are used for wastewater treatment. When compared with the conventional methods available for the treatment of water and wastewater, liquid-liquid extraction-based methods are comparably superior, except for the issue of recyclability of solvents and process economics ${ }^{(56)}$. More research may be carried out to promote wastewater treatment in 
liquid-liquid extraction. In the next sections, special types of liquid-liquid extraction such as reverse micellar extraction, cloud point extraction, supported liquid membrane, bulk liquid membrane, supercritical fluid extraction, microfluidic liquid-liquid extraction, and liquid-liquid extraction using oil will be dealt with.

\section{Reverse Micellar Extraction (RME)}

Reverse micellar extraction is a special type of liquid-liquid extraction that takes place with the help of surfactants ${ }^{(57)}$. Surfactants helps to form the reverse micelles between two phases - extract and raffinate. A strong surface tension exists between the phases, formed by the reverse micelles ${ }^{(58)}$. Liquid-liquid extraction by reverse micelles is a versatile tool for various applications, particularly in wastewater treatment. Reverse micellar extraction, like liquid-liquid phase extraction, is a biphasic phenomenon which involves the partitioning of organic and aqueous phases ${ }^{(59)}$. Hence, reverse micellar extraction could be effectively employed in wastewater treatment. In addition, these systems offer low interfacial tension, ease of scale-up, and continuous operation ${ }^{(60)}$. RME offers several unique, desirable features as follows:

1. The partitioning behaviour of pollutants in RME can be regulated by varying the size and shape of the reverse micelles (RMs). This can be easily accomplished by the self-assembling and labile nature of RMs

2. Partitioning selectivity of pollutants can be achieved in RME based on the hydrophobic nature of pollutants because RMs provide both hydrophobic and hydrophilic environments to solutes simultaneously.

3. Recovery of pollutants from the reverse micellar phase can be easily facilitated by exploiting the de-assembling nature of RMs in aqueous media ${ }^{(61)}$.

Further, the surfactants can be separated from the extract and raffinate phases by filtration and can be recycled. In the past two decades, the potential of RME in wastewater treatment has been demonstrated. RMs have also been used as media for wastewater treatment. Other important applications of RME include tertiary oil recovery, extraction of metals from raw ores, and drug delivery ${ }^{(62)}$. Although many research articles and a few review papers have been published in the past relating to various aspects of RME, no comprehensive review encompassing all aspects is available. Engineering aspects have received scant attention when compared to the physicochemical and biological aspects ${ }^{(63)}$. Special emphasis has been given to some recent applications of RME.

Bukman et al., (2017) focused on the improvement of clarification of the wastewater effluent contaminated with dyes by liquid-liquid extraction induced by reverse micelle followed by phototreatment ${ }^{(64)}$. Methylene blue as model of cationic dye and sodium dodecyl sulphate as anionic surfactant in isoamyl alcohol (immiscible organic solvent toward water) were used. The operation conditions were studied with statistic methodologies. Percentage efficiency and rate of the clarification were used as response. The main experimental parameter was the proportion of alcohol:water, however above $33 \%$ of alcohol the responses were not so different. It is reached more than $96 \%$ of water clarification with $\mathrm{t}_{1 / 2}$ of $46 \mathrm{~min}$. The presence of alcohol remaining in the clarified water was eliminated by photodegradation as demonstrated by GC-MS and by Artemia salina test. One of the key achievements was the recovery of the isoamyl alcohol after the clarification. This dyed alcohol isolated from clarified water was treated using small amount of inorganic acid. This recycled organic solvent was successfully reused to treat new wastewater and this cycle of clarification/recycling was repeated several times. This dye extraction from wastewater by reversed micelles is already described however the present work improves the overall processes making it economically and environmentally attractive.

Ueda et al., (2011) performed the removal of 2-[[(4-methoxyphenyl) methylhydrazono]methyl] -1,3,3-trimethyl-3Hindolium methyl sulfate (Basic Yellow 28), 2-[N-ethyl-4-[(6-methoxy-3-methyl-1,3-benzothiazol-3-ium-2-yl)diazenyl]anilino] ethanol methyl sulfate (Basic Blue 41), N-benzyl-4-[(1,4-dimethyl-1,5-dihydro-1,2,4-triazol-1-ium-5-yl)diazenyl]-Nmethylaniline bromide (Basic Red 46) cationic textile dyes from model wastewater by liquid-liquid extraction with reverse micelles with isopentanol as a solvent and sodium dodecylsulfate as an anionic surfactant ${ }^{(65)}$. The dye concentration in both aqueous and organic phase was determined by visible spectrophotometry analysis. The influence of dye and surfactant initial concentrations on the solute partition coefficient and percentage of removal were studied. The partition coefficient and percentage of removal increase with the decrease in initial dye concentration and with the increase in surfactant concentration.

Pandit and Basu (2002) proposed that solvent extraction using reverse micelles for the removal of organic dyes from water ${ }^{(19)}$. In this approach, the dye is solubilized in the aqueous core of the reverse micelles, which are present in the organic phase. The organic phase is subsequently separated from the aqueous phase leading to significant removal of dye. Experimental results reveal that the electrostatic interaction between the oppositely charged surfactant head group present in the reverse micelles and the dye molecule plays a key role in the separation. The removal of the anionic methyl orange dye from water is carried out in the presence of cationic hexadecyl trimethyl ammonium bromide surfactant, whereas the removal of the cationic methylene blue dye is carried out in the presence of anionic sodium dodecylbenzene sulfonate surfactant. Amyl alcohol is used as the solvent. 
The influence of parameters such as dye concentrations, surfactant concentrations, $\mathrm{pH}$, and $\mathrm{KCl}$ and $\mathrm{NaBr}$ concentrations on the percentage removal of dye was studied. The percentage removal of dye is decreased with the increase in dye concentration in the feed. The increase in surfactant concentration resulted in higher dye removal because more reverse micelles could be hosted in the organic phase. The increase in aqueous phase $\mathrm{pH}$ resulted in enhanced removal of methyl orange from water, while in the case of methylene blue the percentage removal decreased. The increase in $\mathrm{KCl}$ and $\mathrm{NaBr}$ concentrations resulted in decreased percentage removal of methylene blue, whereas the percentage removal of methyl orange was increased. The effect of $\mathrm{pH}$ and salt concentration is explained based on charge transfer mechanism and electrostatic interactions and dye-surfactant complex formation.

Pandit and Basu (2004a) proposed a new technique based on liquid/liquid extraction using reverse micelles whereby recovery of solvent and reuse of dye is possible ${ }^{(66)}$. Several methods (e.g., $\mathrm{UV} / \mathrm{H}_{2} \mathrm{O}_{2}$ oxidation, adsorption, flocculation-precipitation) are normally employed to remove dye from water. Experiments were conducted by mixing a known quantity of dye in an aqueous phase and solvent-containing surfactants in a simple mixer. The separation of solvent phase, containing encapsulated dye in reverse micelles, from aqueous phase due to gravity results in the separation of dye from water. The removal of different ionic dyes (e.g., eosin yellow, methylene blue, malachite green, methyl orange, orange $G$ ) from the aqueous phase in the presence of different cationic and anionic surfactants [e.g., sodium dodecylbenzene sulfonate, sodium bis(2-ethylhexyl) sulfosuccinate, hexadecyltrimethylammonium bromide, and cetyl pyridinium chloride] in different solvents (e.g., amyl alcohol, benzyl alcohol, methyl benzoate, and isooctane) were studied by conducting experiments. The percentage removal of dye from the aqueous phase increases with the decrease in dye concentration or with the increase in surfactants concentration. Furthermore, the percentage of COD removal of dye is increased with the increase in surfactant concentration. The nature of solvent has minimal effect on the percentage removal of dye. The ratio of solvent to aqueous phase volume required for the removal of dye decreases with the increase in surfactant concentration. It is possible to back-extract dye into the aqueous phase and recovers solvent by using counterionic surfactants. The separation of the aqueous phase from the aqueous-phase solvent dispersion is faster for amyl alcohol as compared to benzyl alcohol and methyl benzoate. A theoretical model based on the ion-exchange reaction between surfactants and dye is used to analyse the experimental data.

Pandit and Basu (2004b) studied the backward extraction or the recovery into an aqueous phase from the solvent phase by using a counterionic surfactant after investigating forward extraction experimentally using a simple mixer and settler arrangement ${ }^{(67)}$. Among the several methods, dye removal from water by solvent extraction using reverse micelles is promising in the terms of the simplicity and efficiency of the process. The effects of different parameters, such as the surfactant concentration, $\mathrm{pH}$, and $\mathrm{KCl}$ concentration on the recovery of methyl orange and methylene blue dye, are investigated. The percentage of both cationic and anionic dyes recovered increases with the increase in the counterionic surfactant concentration or with the decrease in the $\mathrm{KCl}$ concentration. The percentage of recovery of anionic methyl orange increase with a decrease in $\mathrm{pH}$, whereas that for cationic methylene blue increases with an increase in $\mathrm{pH}$. Selective removal of dye from a cationic and anionic dye mixture was experimentally studied by treating the dye mixture with reverse micelles of anionic and cationic surfactants in a stepwise manner.

Noritomi et al., (2009) investigated the extraction of methyl orange or methylene blue from an aqueous phase to an organic phase of reverse micelles of alkyl glucosides ${ }^{(68)}$. Dodecyl glucoside, a biodegradable and biocompatible surfactant, was employed as a kind of alkyl glucosides since a stable Winsor II system consisting of the water-in-oil type microemulsion and aqueous phases was formed when an organic solution containing dodecyl glucoside was contacted with an aqueous solution. The water content in the reverse micellar organic phase increased with an increase in the concentration of dodecyl glucoside. The extraction ratio of dyes also increased with increasing the concentration of dodecyl glucoside. Furthermore, the extraction ratio of dyes was dramatically dependent upon the $\mathrm{pH}$ of an aqueous phase and temperature.

Feitosa et al., (2008) established a partial pseudo-ternary phase diagram for the cetyl trimethyl ammonium bromide/ isooctane:hexanol: butanol/ potassium phosphate buffer system where the two-phase diagrams consisting of the reverse micelle phase (L2) in equilibrium with the solvent ${ }^{(69)}$. Based on the diagrams two-phase systems of reverse micelles were prepared with different compositions of the compounds and used for extraction and recovery of two enzymes, and the percentage of enzyme recovery yield monitored. The enzymes glucose-6-phosphate dehydrogenase (G6PD) and xylose reductase (XR) obtained from Candida guilliermondii yeast were used in the extraction procedures. The recovery yield data indicate that micelles having different compositions give selective extraction of enzymes. The method can thus be used to optimize enzyme extraction processes. Table 3 summarizes the reverse micellar extraction for the removal of various dyes. 
Table 3. Reverse micellar extraction for the removal of dyes

\begin{tabular}{|c|c|c|c|c|c|}
\hline S. No. & Dye & Solvent & \% Removal & Parameters studied & Reference \\
\hline 1 & $\begin{array}{l}\text { Methyl orange and methy- } \\
\text { lene blue/ potassium chlo- } \\
\text { ride }\end{array}$ & $\begin{array}{l}\text { Amyl alcohol/sodium dodecyl- } \\
\text { benzene sulfonate and hexadecyl } \\
\text { trimethyl ammonium bromide }\end{array}$ & $90-100 \%$ & $\begin{array}{l}\text { Surfactant concen- } \\
\text { tration, } \mathrm{pH} \text {, and } \mathrm{KCl} \\
\text { concentration }\end{array}$ & $(66)$ \\
\hline 2 & $\begin{array}{l}\text { Methyl orange and methy- } \\
\text { lene blue/ } \mathrm{KCl}, \mathrm{NaBr}\end{array}$ & $\begin{array}{l}\text { Amyl alcohol/sodium dodecyl- } \\
\text { benzene sulfonate and hexadecyl } \\
\text { trimethyl ammonium bromide }\end{array}$ & $<95 \%$ & $\begin{array}{l}\text { Dye concentration, } \mathrm{pH} \text {, } \\
\mathrm{KCl} \text {, and } \mathrm{NaBr} \text { concen- } \\
\text { tration }\end{array}$ & (67) \\
\hline 3 & Reactive Blue $171 / \mathrm{NaCl}$ & $\begin{array}{l}\text { Amyl alcohol/Hexadecyl trimethyl } \\
\text { ammonium bromide and Sodium } \\
\text { dodecylbenzene sulfonate }\end{array}$ & $85 \%$ & $\begin{array}{l}\text { Suspended solids and } \\
\text { total dissolved solids } \\
\text { and physical \& chemical } \\
\text { properties of the fabric }\end{array}$ & (68) \\
\hline 4 & $\begin{array}{l}\text { Reactive Blue } 171 \text {, reactive } \\
\text { red } 141 \text {, and reactive yel- } \\
\text { low } 84 / \mathrm{NaCl}\end{array}$ & $\begin{array}{l}\text { Isoamyl alcohol/Hexadecyl trimethyl } \\
\text { ammonium bromide and Sodium } \\
\text { dodecylbenzene sulfonate }\end{array}$ & $74-97 \%$ & $\begin{array}{l}\text { Surfactant concentra- } \\
\text { tion, } \mathrm{pH} \text {, and electrolyte } \\
(\mathrm{NaCl}) \text { concentration }\end{array}$ & (69) \\
\hline
\end{tabular}

\section{Cloud Point Extraction}

Cloud point extraction (CPE) is one of the best alternative techniques that can be used for the extraction of a wide range of organic and inorganic components using green surfactants such as rhamnolipids, rhamnosides, and glucosides ${ }^{(70)}$. It is a simple, rapid, and inexpensive extraction technique which involves clustering of non-ionic surfactant monomers to form a hydrophobic core (micelle), which then entraps the hydrophobic bioactive compounds within it. CPE can be applied for wastewater treatment, as well as extraction of bioactive components from food processing waste, and separation and purification of proteins $^{(71)}$.

Tatara et al., (2005) studied that the cloud point separation of Direct Yellow from a micellar solution of various non-ionic surfactants, containing a polyoxyethylene chain ${ }^{(20)}$. The separation of dyes is an important environmental problem. Moreover, such separation can also be considered as a preliminary step for further studies of biochemical recovery. Some dyes can be considered as affinity ligands, which form complexes with biochemicals. The use of dye enabled the observation of the dynamics of surfactant-rich phase separation by means of a colour video. It was found that the separation of phases was incomplete. The aqueous phase contained some amounts of surfactant globules with the dye. The surfactant-rich phase was usually more heterogenic than the aqueous phase. The recovery of Direct Yellow was very effective in the presence of an electrolyte $(\mathrm{NaCl})$. The distribution coefficients were high and equal to a few hundred in the presence of sodium chloride. Under optimum conditions, $98-99.9 \%$ of the dye could be removed in one step.

Purkait et al., (2003) attempted to remove the colour from wastewater containing toxic eosin dye (anionic dye) by cloud point extraction (CPE) in batch mode using a non-ionic surfactant, Triton X-100 (TX-100) ${ }^{(72)}$. Most of the dye molecules get solubilized in the coacervate phase leaving a colour-free dilute phase. The effects of the concentration of feed mixture, temperature, and salt concentration on the concentration of both dye and surfactant in the coacervate phase and dilute phase have been studied after the complete separation of the two phases. Experimental investigations have also been carried out for the recovery of surfactant from dilute phase applying solvent extraction (SE) in batch conditions. It has been observed that 87.5100 percent eosin removal is possible for the feed dye concentration of up to $200 \mathrm{ppm}$ using $0.1(\mathrm{M})$ of TX-100 and $0.2(\mathrm{M})$ of salt $(\mathrm{NaCl})$ at $80^{\circ} \mathrm{C}$. About 88 percent of TX-100 can be recovered from the dilute phase using the solvent extraction method. It is concluded that the cloud point extraction techniques for dye removal may be an alternative to the present dye removal processes.

Duran et al., (2011) revealed that Cloud-point extraction (CPE) using the non-ionic surfactant Triton X-100 was used successfully to remove a highly toxic dye, rhodamine $6 \mathrm{G}(\mathrm{R} 6 \mathrm{G})$, from water and wastewater ${ }^{(73)}$. The effects of different analytical parameters such as $\mathrm{pH}$, the concentration of Triton X-100 (TX-100) and salts, equilibrium temperature, and incubation time on the efficiency of the extraction of R6G were studied in detail, and optimum conditions for dye extraction were obtained. Thermodynamic parameters including changes in Gibbs free energy, enthalpy, and entropy were also calculated, and these parameters indicated that the CPE of R6G was feasible, spontaneous, and endothermic in the temperature range of $75-95^{\circ} \mathrm{C}$. The equilibrium solubilization capacity of TX-100 was found to be $1.10 \mathrm{mmol} / \mathrm{mol}$ by using Langmuir isotherm models. No significant interference effects were observed in the presence of phenol and its derivatives, some acidic and basic dyes, and most of the anions and cations. It was concluded that the CPE process described in this paper can be an alternative technique for the removal of dyes and other pollutants from waters and wastewaters. 
Arunagiri et al., (2012) examined Cloud Point Extraction (CPE), which is a separation technique based on phase separation properties of non-ionic surfactants above the cloud point temperature and the solubilization phenomena of coacervate micelles (surfactant rich phase) ${ }^{(74)}$. Cloud point extraction exhibits many attractive advantages such as simplicity, low cost, high enrichment factor, non-flammable, non-volatile, and less toxic surfactants, moderate extraction conditions, and friendliness to the environment. For better operation and the design of CPE, it is necessary to study the factors affecting CPE such as surfactant concentration, solute concentration, electrolyte concentration, and operating temperature. In the present study, the removal of Reactive blue dye from water using CPE has been carried out using Triton X -100 as a non-ionic surfactant. The effect of electrolytes on cloud point extraction has been studied using $\mathrm{NaCl}$ salt. The experiments are conducted for a different set of surfactants $(0.01 \mathrm{M}$ to $0.05 \mathrm{M})$, solute $(25 \mathrm{ppm}, 50 \mathrm{ppm}, 75 \mathrm{ppm})$, and salt concentrations $(0.1 \mathrm{M}$ to $1 \mathrm{M})$ to find out the cloud point temperature and the effect of these parameters on the cloud point temperature. The extraction efficiency, phase volume ratio, distribution coefficient, and pre-concentration factor were also found for different operating conditions (Surfactant, salt concentrations, and operating temperature). Thermodynamic studies have also been conducted.

Mazzola et al., (2008) attempted to remove the colour from wastewater containing Congo red (a toxic cationic dye) by surfactant mediated cloud point extraction (CPE) in batch mode using Triton X-100 (TX-100) as a non-ionic surfactant ${ }^{(75)}$. Most of the dye molecules get solubilized in the coacervate phase leaving a dye-free dilute phase. The effects of the concentration of feed mixture (both dye and surfactant), temperature, and salt concentration on the concentration of both dye and surfactant in the coacervate phase and dilute phase have been studied. An optimum set of surfactant concentrations, temperature, and salt concentration are obtained for the removal of dye. Experimental investigations have also been carried out for the recovery of surfactant from dilute phase applying solvent extraction (SE) in batch condition using heptane as extracting medium.

Pourreza and Elhami (2010) developed a surfactant mediated cloud point extraction (CPE) procedure to remove the colour from wastewater containing malachite green using Triton X-100 as a non-ionic surfactant ${ }^{(76)}$. The effects of the concentration of the surfactant, temperature, and salt concentration on the different concentrations of dye have been studied and optimum conditions were obtained for the removal of malachite green. The concentration of malachite green in the dilute phase was measured using a UV-vis spectrophotometer. It was found that the separation of phases was complete, and the recovery of malachite green was very effective in the presence of $\mathrm{NaCl}$ as an electrolyte. The results showed that up to $500 \mathrm{ppm}$ of malachite green can quantitatively be removed (95\%) by CPE procedure in a single extraction using optimum conditions.

Purkait et al., (2009) investigated the thermodynamics of cloud point extraction (CPE) of three different dyes ${ }^{(77)}$. The dyes used are Congo red, Eosin, and Chrysoidine. Iso-octyl phenoxy poly ethoxy ethanol (TX-100) and octyl phenol polyethylene glycol ether (TX-114) are used as a non-ionic surfactant. The effects of different operating conditions (e.g., temperature and concentrations of surfactants and dyes) on various thermodynamic parameters such as a change in Gibbs free energy $\left(\Delta \mathrm{G}^{0}\right)$, change in enthalpy $\left(\Delta \mathrm{H}^{0}\right)$, and change in entropy $\left(\Delta \mathrm{S}^{0}\right)$ are observed and presented in detail. It is found that the values of $\Delta \mathrm{G}^{0}$ increase with temperature but decrease with the concentrations of surfactant and dye. The values of $\Delta \mathrm{H}^{0}$ and $\Delta \mathrm{S}^{0}$ increase with surfactant concentration but decrease with dye concentration. Comparisons of all the thermodynamic parameters are made for chrysoidine-TX-100 and chrysoidine-TX-114 systems. Negative values of $\Delta \mathrm{G}^{0}$ of all three dyes dictate that the solubilizations are spontaneous phenomena. The endothermic nature of the solubilization process of all dye is governed by the positive value of $\Delta \mathrm{H}^{0}$. On the other hand, positive values of $\Delta \mathrm{S}^{0}$ prove that dye molecules are organized on the mantle of aqueous hydrophilic chains in a more random fashion.

\section{Liquid Membrane Extraction}

A liquid membrane (LM) is formed by a thin layer of the organic phase (usually with dissolved reagents) between two aqueous phases of different compositions ${ }^{(78)}$. LM is a relatively new and prospective separation system consisting of a liquid film through which selective mass transfers of gases, ions, or molecules occur via permeation and transport processes. Different types of liquid membranes used for the separation of metal ions are (i) emulsion liquid membranes (ELM), (ii) bulk liquid membranes (BLM), and (iii) supported liquid membranes (SLM) ${ }^{(22)}$.

The emulsion liquid membrane and bulk liquid membranes are non-supported liquid membranes and flat sheet liquid membranes, and hollow fibre liquid membranes are supported liquid. In supported liquid membrane microporous films are used as the solid support ${ }^{(21)}$. This thin layer of organic phase can be immobilized onto a suitable inert microporous support, which when interposed in between two aqueous solutions is termed supported liquid membrane (SLM) ${ }^{(18)}$. In this three-phase extraction technique and analytes are extracted from a continuously flowing aqueous sample through an organic liquid phase into another usually temporarily stagnant, aqueous phase.

Bulk liquid membrane (BLM) consists of a bulk aqueous feed and receiving phases separated by a bulk organic, waterimmiscible liquid phase. The feed and receiving phases may be separating from the LM by microporous supports or maybe without supports ${ }^{(21)}$. 
Hajarabeevi et al., (2009) studied and determined that the transport of cationic dyes methyl violet and rhodamine B from aqueous synthetic dye solution through flat type supported liquid membranes (SLM) using di (2-Ethylhexyl) phosphoric acid (D2EHPA) as a carrier and the parameters affecting the dyes transport ${ }^{(18)}$. The extraction was carried out from the aqueous feed phase with $\mathrm{pH} 4 \pm 0.2$ to a more acidic strip phase of acetic acid with $\mathrm{pH} 2.5$. The proton gradient between the feed and the strip phase was the main driving force of the mass transfer in this system. The influence of various parameters such as $\mathrm{pH}$ of the feed phase, strip phase concentration, carrier concentration, stirring speed and the concentration of dyes on the extraction efficiency was studied. Kinetics of transport was also studied. The optimum conditions of transport are feed phase pH $4 \pm 0.2$, acetic acid as stripping phase with $\mathrm{pH} 2.5$, stirring speed at $600 \mathrm{rpm}$. The maximum recovery under optimum conditions was observed as $94.2 \%$ for methyl violet and $90.0 \%$ for rhodamine B.

Muthuraman et al., (2010) investigated the transport of cationic dye from an aqueous feed solution through a flat-type supported liquid membrane containing di-(2-ethyl hexyl) phosphoric acid as a carrier ${ }^{(79)}$. The influence of $\mathrm{pH}$ on the source phase, the effect of the concentration of the receiving phase, the stirring speed, the effect of the initial dye concentration, the feed-to-strip ratio, and the influence of the support characteristics were studied. A polytetrafluoroethylene membrane with a 1.0 $\mu \mathrm{m}$ pore size was found to have more permeability than that with a pore size of $0.5 \mu \mathrm{m}$. The results indicated that the aqueous feed solution at an alkaline $\mathrm{pH}$ has high permeability. The initial feed phase dye can be completely extracted and stripped with a stripping solution within $7 \mathrm{~h}$.

Memon et al., (2014) employed calix[6]arene-based derivative (1) as a selective carrier for the efficient transport of methyl red $(\mathrm{MR})$ through bulk liquid membrane $(\mathrm{BLM})^{(80)}$. Initially, the selectivity of 1 towards MR was confirmed among different dyes, such as methyl green (MG), methyl violet (MV), methylene blue (MB), methyl orange (MO), and eosin gelblich (EG) by liquid-liquid extraction experiments. Furthermore, the effect of the initial $\mathrm{MR}$ concentration of salts $\left(\mathrm{NaCl}, \mathrm{Na}_{2} \mathrm{SO}_{4}\right.$, and $\mathrm{Na}_{2} \mathrm{CO}_{3}$ ) and of the $\mathrm{pH}$ of the acceptor phase were also optimized using liquid-liquid extraction. Afterwards, the influence of basic parameters, such as carrier concentration in membrane phase, type of solvent, and stirring rate on MR transport was determined through BLM. Mass transfer of MR through BLM was analyzed by following the kinetic laws of two consecutive irreversible first-order reactions, and the kinetic parameters $\left(\mathrm{k}_{1}, \mathrm{k}_{2}, R_{m}^{\max }, \mathrm{t}_{\max }, J_{a}^{\max }, J_{d}^{\max }\right)$ were also calculated. Apparently, increase in membrane entrance $\left(\mathrm{k}_{1}\right)$ and exit rate $\left(\mathrm{k}_{2}\right)$ constants was accompanied by a rise in carrier concentration under a high stirring rate. In addition, $\mathrm{CH}_{2} \mathrm{Cl}_{2}$ proved to be a better solvent than $\mathrm{CHCl}_{3}$ and $\mathrm{CCl}_{4}$. The $\%$ transport of $\mathrm{MR}$ was $99 \%$ across the liquid membrane under optimized conditions. Real textile industrial wastewater samples gave also appreciable results in BLM under optimized conditions.

Muthuraman and Palanivelu, (2005) presented membrane extraction of anionic dyes using Bulk Liquid Membrane with cationic tetra butyl ammonium bromide (TBAB) ${ }^{(21)}$. The results reveal that TBAB has been a very effective reagent for the selective extraction of anionic dyes from an aqueous solution. The solution of TBAB (0.05\%) in methylene chloride (100ml) can extract about $98 \%$ of 50ppm concentration of Golden Yellow and Cibacron Red dyes. The experiments were carried out at 27 ${ }^{\circ} \mathrm{C}$. Extracted dye in the organic phase can be back-extracted from salicylic acid and sodium carbonate solution. After salicylic acid, sodium carbonate stripping, and water washing, the organic layer of TBAB becomes regenerated and can be recycled for further extraction. The stripped solution on acidification precipitated salicylic acid and the dye is recovered. Table 4 shows the liquid membrane-based systems for the removal of dyes.

Table 4. Liquid membrane-based systems for the removal of dyes

\begin{tabular}{llllll}
\hline S. No. & Dye & Solvent & \% Removal & Liquid membrane system & Reference \\
\hline 1 & Methyl red & calix[6]arene & 99 & BLM & $(23)$ \\
2 & Methylene blue & Salicylic acid & 93 & BLM & $(23)$ \\
3 & Crystal violet & Edible paraffin oil: heptane (4:1) & 95 & ELM & $(23)$ \\
4 & Methyl violet & Edible paraffin oil: heptane (4:1) & 96 & ELM & $(23)$ \\
5 & Astacryl golden yellow & Palm oil & 91 & SLM & $(23)$ \\
6 & Rhodamine B & Sunflower oil & 92 & SLM & $(23)$ \\
\hline
\end{tabular}

\section{Advanced liquid-liquid extraction methods}

Montero et al., (2000) in an overview revealed that considering environmental concerns, the textile industry has accelerated efforts to reduce or eliminate water consumption in all areas of yarn preparation, dyeing, and finishing ${ }^{(81)}$. Supercritical fluid dyeing technology has the potential to accomplish this objective in many commercial textile applications around the world, both at present and in the future around the world. Increased interest in this technology has made a fundamental understanding of thermophysical (equilibrium solubility) and transport (kinetics) properties of such fluids and fluid mixtures necessary. 
Supercritical carbon dioxide ( $\mathrm{SC}-\mathrm{CO}_{2}$ ) is one of the most environmentally acceptable solvents in use today, and textile processes using it have many advantages when compared to conventional aqueous processes. Positive environmental effects range from drastically reduced water consumption to eliminating hazardous industrial effluent. Furthermore, economic benefits include increased productivity and energy savings. Successfully commercializing supercritical fluid $\mathrm{CO}_{2}$ processing will improve the economics of dyeing and other textile chemical processes by eliminating water usage and wastewater discharges and increasing productivity by reducing processing times as well as required chemicals, auxiliaries, reducing energy consumption and air emissions. As a result, $\mathrm{SC}-\mathrm{CO}_{2}$ processing will be more rapid, more economical, and more environmentally friendly.

Santos et al., (2001) studied the effects of modifying agents and dyeing conditions of dispersed for Polyethylene Terephthalate (PET) films and fibres ${ }^{(82)}$. This research reports on the dye incorporation process of non-modified and $\mathrm{N}, \mathrm{N}$-dimethyl acrylamide modified PET fibres with supercritical $\mathrm{CO}_{2}$. Spectral analysis in the infrared region to the modified PET fibres showed peaks of the modifier, but the thermal stability of the modified fibre did not show variation when compared with the non-modified. The amount of disperse dye incorporated in the PET fibres was determined by UV-vis spectroscopy at $579 \mathrm{~nm}$ through the dye extraction using $\mathrm{N}, \mathrm{N}$-dimethylformamide. A $2^{\wedge} 4$ factorial design was realized with the purpose to study the influence of variables in the dye incorporation process as well as their interaction effects. The pre-treatment of the PET fibres with $\mathrm{N}, \mathrm{N}$-dimethyl acrylamide increases the amount of incorporated dye 3.8 times, on average.

Abbasi et al., (2021) presented a study on the removal of methylene blue (MB) and thymol blue (TB) dyes from contaminated water using a mono-and di-ester mixture (MDEHPA) as the extractant in a Y-Y junction microchannel ${ }^{(83)}$. Nowadays, the innovative processes for refining industrial dye wastewater are often used to reduce the toxicity of these pollutants due to satisfy the treatment standard operating parameters such as aqueous solution $\mathrm{pH}$ extractant and residence time were optimized. The maximum rates of $\mathrm{TB}$ and $\mathrm{MB}$ extraction were achieved to be $97.9 \%$ and $98.4 \%$, respectively. Mass transfer performance is surveyed using overall volumetric mass transfer coefficient determination $\left(\mathrm{k}_{L} \alpha\right)$.

Kaur et al., (2018) prepared and applied glycolic acid and choline chloride based deep eutectic solvents (DESs) to explore its capability for Eriochrome black T (EBT) dye extraction from aqueous solution using liquid-liquid micro-extraction ${ }^{(84)}$. The effects of $\mathrm{pH}, \mathrm{DESs}$ dose and dye concentration on \% extraction efficiency were studied and reported. To explore its extraction capability, the partition coefficient was also calculated. Furthermore, molecular interaction between EBT dye and DESs were explored to understand the extraction mechanism. DESs prepared exhibited high viscosities $(>200 \mathrm{cP})$ showing the presence of extensive hydrogen bond between the components of DES. High density of DESs prepared (1.31-01.41 $\mathrm{g} \mathrm{cm}^{-3}$ ) (comparable to ionic liquids), indicates its suitability as solvent for the extraction processes. It was observed that EBT dye molecule in zwitterionic form preferred to be partitioned in DES, while in anionic form in water.

Gharehbaghi and Shemirani (2012) applied a novel, simple, fast, and efficient ionic liquid-based dispersive liquid-liquid extraction (IL-DLLE) to extract and remove Congo Red (CR; a carcinogenic textile dye) from aqueous solutions ${ }^{(85)}$. In this methodology a binary solution, containing the extraction solvent (1-hexyl-3-methylimmidazolium bis(trifluormethylsulfonyl) imid) and a suitable disperser solvent, was rapidly injected into the water sample containing CR dye. Therewith, a cloudy solution was formed, and most of the dye molecules were extracted into fine IL droplets and removed from aqueous phase. The effects of $\mathrm{pH}$, type, and amount of IL, initial concentration of the dye, type and volume of the dispersant, and concentrations of salt on the extraction of the dye were studied. Experimental surveys were also accomplished for recovery of the IL by applying a reverse dispersive liquid-liquid extraction using acidic stripping solutions.

Kralj et al., (2005) developed a two-parameter model to quantify the extraction behaviour and demonstrate the effectiveness of reverse micelle enhanced extraction by varying the surfactant concentration $1-10 \mathrm{wt} . \%{ }^{\left({ }^{(8)}\right.}$. Continuous microfluidic liquidliquid extraction is realized in a microfluidic device by generating emulsions with large interfacial areas for mass transfer, and subsequently breaking these emulsions using electric fields into easily separated segments of immiscible liquids (plugs). The microfluidic device employs insulated electrodes in a potassium hydroxide-etched channel to create large electric fields (100 $\mathrm{kV} \mathrm{m} 21$ ) that drive the coalescence of the emulsion phase. The result is a transition from dispersing to slug flow that can then readily be separated by gravity. Extractions of phenol and p-nitrophenol from an aqueous to hexane-surfactant solution serve as model systems. In addition to the increased surface area in the emulsion, extraction efficiency is enhanced by reverse micelles resulting from the presence of surfactants.

Mahmoud et al., (2007) evaluated the effectiveness of five plant oils (cottonseed, olive, canola sunflower, and used cooking oil) for the removal of dye from textile wastewater ${ }^{(87)}$. Oils are used to enhance stability between layers. The study revealed that the dye removal efficiency increased as the temperature was increased. Under low $\mathrm{pH}$, both the oil and dye split into two components each. Neither one of the oil components joined with either one of the dye components. However, the observed reduction in the absorbance under acidic conditions can be attributed to the dye components losing some of their original colour or producing different colours that were not effectively measured at $475 \mathrm{~nm}$. When the dye solution was shaken with the oil under alkaline conditions, it formed a colloidal solution containing the oil plus the dye, resulting in significant dye removal 
from the solution. The results also showed that the optimum conditions for the dye removal for various oils were at a $\mathrm{pH}$ of 13 and a temperature of $55^{\circ} \mathrm{C}$, except for canola oil that produced the highest dye removal efficiency at $\mathrm{pH}$ of 7 . The used cooking oil achieved the highest dye removal efficiency (95.45\%) followed by olive oil ( $87.00 \%)$. The other oils (cottonseed, canola, and sunflower achieved dye removal efficiencies below $58 \%$ and are, therefore, not recommended for dye removal.

Summarizing all the discussed reviews, it is observed that a liquid-liquid extraction system could be a potential tool for the treatment of wastewater. Considering the hazardous effects of dyehouse effluents, liquid-liquid extraction has few limitations such as scaling-up, recyclability of solvents, etc.

\section{CONCLUSION}

The presented review focused on various extraction systems used in wastewater treatment. A lot of water was discharged as waste in soil and water, treatment of such wastewater becomes essential. When compared with the conventional methods available for the treatment of water and wastewater, liquid-liquid extraction-based methods are comparably superior, except for the issue of recyclability of solvents. An overview of liquid-liquid extraction and its systems such as conventional liquid-liquid extraction, reverse micellar liquid extraction, cloud point extraction, emulsion liquid membrane, supported liquid membrane, bulk liquid membrane, supercritical fluid extraction, microfluidic liquid-liquid extraction, and extraction using oil were presented in the manuscript. The limitation of the manuscript is that cost effectiveness is not dealt with. Unlike conventional wastewater methods, researchers perform various research on wastewater treatment using solvent extraction systems with economic analysis.

\section{References}

1) Sivamani S. Batch adsorption studies for chromium removal. Journal of environmental science \& engineering. 2008;50(1):11-16. Available from: https://pubmed.ncbi.nlm.nih.gov/19192921/.

2) Sivamani S, Prasad BSN, Nithya K, Sivarajasekar N, Hosseini-Bandegharaei A. Back-propagation neural network: Box-Behnken design modelling for optimization of copper adsorption on orange zest biochar. International Journal of Environmental Science and Technology. 2021;p. 1-16. Available from: https://dx.doi.org/10.1007/s13762-021-03411-1.

3) Sivamani S, Leena GB. Removal of dyes from wastewater using adsorption-a review. Int J Biosci Technol. 2009;2(4):47-51. Available from: https: //www.researchgate.net/publication/305378563_Removal_of_dyes_from_wastewater_using_adsorption.

4) Sivarajasekar N, Mohanraj N, Sivamani S, Maran JP, Moorthy IG, Balasubramani K. Statistical optimization studies on adsorption of ibuprofen onto Albizialebbeck seed pods activated carbon prepared using microwave irradiation. Materials Today: Proceedings. 2018;5(2):7264-7274. Available from: https://dx.doi.org/10.1016/j.matpr.2017.11.394.

5) Robinson T, McMullan G, Marchant R, Nigam P. Remediation of dyes in textile effluent: a critical review on current treatment technologies with a proposed alternative. Bioresource Technology. 2001;77(3):247-255. Available from: https://dx.doi.org/10.1016/s0960-8524(00)00080-8.

6) Marsousi S, Karimi-Sabet J, Moosavian MA, Amini Y. Liquid-liquid extraction of calcium using ionic liquids in spiral microfluidics. Chemical Engineering Journal. 2019;356:492-505. Available from: https://dx.doi.org/10.1016/j.cej.2018.09.030.

7) Tarkwa JB, Oturan N, Acayanka E, Laminsi S, Oturan MA. Photo-Fenton oxidation of Orange G azo dye: process optimization and mineralization mechanism. Environmental Chemistry Letters. 2019;17(1):473-479. Available from: https://dx.doi.org/10.1007/s10311-018-0773-0.

8) Mecha AC, Chollom MN. Photocatalytic ozonation of wastewater: a review. Environmental Chemistry Letters. 2020;18(5):1491-1507. Available from: https://dx.doi.org/10.1007/s10311-020-01020-x.

9) Guo Q, Zhou C, Ma Z, Yang X. Fundamentals of TiO 2 Photocatalysis: Concepts, Mechanisms, and Challenges. Advanced Materials. 2019;31(50):19019971901997. Available from: https://doi.org/10.1002/adma.201901997.

10) Radjenovic J, Sedlak DL. Challenges and Opportunities for Electrochemical Processes as Next-Generation Technologies for the Treatment of Contaminated Water. Environmental Science \& Technology. 2015;49(19):11292-11302. Available from: https://dx.doi.org/10.1021/acs.est.5b02414.

11) Brezinski K, Gorczyca B, Sadrnourmohammadi M. Ion-exchange for trihalomethane control in potable water treatment - a municipal water treatment case study in Rainy River, Ontario, Canada. Water Quality Research Journal. 2019;54(2):142-160. Available from: https://dx.doi.org/10.2166/wqrj.2018.134.

12) Hasan HA, Muhammad MH. A review of biological drinking water treatment technologies for contaminants removal from polluted water resources. Journal of Water Process Engineering. 2020;33:101035-101035. Available from: https://doi.org/10.1016/j.jwpe.2019.101035.

13) Buthiyappan A, Raman AAA, Daud WMAW. Development of an advanced chemical oxidation wastewater treatment system for the batik industry in Malaysia. RSC Advances. 2016;6(30):25222-25241. Available from: https://dx.doi.org/10.1039/c5ra26775g.

14) Joaquin AA, Nirmala G. Statistical modeling and process optimization of coagulation-flocculation for treatment of municipal wastewater. Desalination and Water Treatment. 2019;157:90-99. Available from: https://dx.doi.org/10.5004/dwt.2019.24162.

15) Shahmansouri A, Bellona C. Nanofiltration technology in water treatment and reuse: applications and costs. Water Science and Technology. 2015;71(3):309319. Available from: https://dx.doi.org/10.2166/wst.2015.015.

16) Parvathi C. Role of tapioca peel activated carbon (TPAC) in decolourisation of Red Brown C4R reactive dye. Indian Journal of Science and Technology. 2010;3(3):290-292. Available from: https://dx.doi.org/10.17485/ijst/2010/v3i3.14.

17) Muthuraman G, Teng TT. Extraction of methyl red from industrial wastewater using xylene as an extractant. Progress in Natural Science. 2009;19(10):12151220. Available from: https://dx.doi.org/10.1016/j.pnsc.2009.04.002.

18) Hajarabeevi N, Bilal IM, Easwaramoorthy D, Palanivelu K. Facilitated transport of cationic dyes through a supported liquid membrane with D2EHPA as carrier. Desalination. 2009;245(1-3):19-27. Available from: https://dx.doi.org/10.1016/j.desal.2008.06.009.

19) Pandit P, Basu S. Removal of Organic Dyes from Water by Liquid-Liquid Extraction Using Reverse Micelles. Journal of Colloid and Interface Science. 2002;245(1):208-214. Available from: https://dx.doi.org/10.1006/jcis.2001.7939. 
20) Tatara E, Materna K, Schaadt A, Bart HJ, Szymanowski J. Cloud Point Extraction of Direct Yellow. Environmental Science \& Technology. 2005;39(9):31103115. Available from: https://dx.doi.org/10.1021/es049381x.

21) Muthuraman G, Palanivelu K. Transport of textile anionic dyes using cationic carrier by bulk liquid membrane. Journal of Scientific and Industrial Research. 2005;64:529-533. Available from: http://nopr.niscair.res.in/bitstream/123456789/5162/1/JSIR\%2064(7)\%20529-533.pdf.

22) Kusumastuti A, Anis S, Syamwil R, Ahmad AL, , and. Emulsion Liquid Membrane for Textile Dyes Removal: Extraction Process. Journal of Physical Science. 2018;29(Supp. 2):175-184. Available from: https://dx.doi.org/10.21315/jps2018.29.s2.13.

23) Chang SH. Utilization of green organic solvents in solvent extraction and liquid membrane for sustainable wastewater treatment and resource recovery-a review. Environmental Science and Pollution Research. 2020;27(26):32371-32388. Available from: https://doi.org/10.1007/s11356-020-09639-7.

24) Antony FM, Pal D, Wasewar K. Separation of bio-products by liquid-liquid extraction. Physical Sciences Reviews. 2021;6(4). Available from: https://dx.doi.org/10.1515/psr-2018-0065.

25) Khraisheh M, AlMomani F, Inamdar M, Hassan MK, Al-Ghouti MA. Ionic liquids application for wastewater treatment and biofuel production: A mini review. Journal of Molecular Liquids. 2021;337:116421-116421. Available from: https://dx.doi.org/10.1016/j.molliq.2021.116421.

26) Álvaro Santana-Mayor, Socas-Rodríguez B, Rodríguez-Ramos R, Herrera-Herrera AV, Ángel Rodríguez-Delgado M. Quality assessment of environmental water by a simple and fast non-ionic hydrophobic natural deep eutectic solvent-based extraction procedure combined with liquid chromatography tandem mass spectrometry for the determination of plastic migrants. Analytical and Bioanalytical Chemistry. 2021;413(7):1967-1981. Available from: https://dx.doi.org/10.1007/s00216-021-03166-1.

27) Rahi MN, Jaeel AJ, Abbas AJ. Treatment of petroleum refinery effluents and wastewater in Iraq: A mini review. IOP Conference Series: Materials Science and Engineering. 2021;1058(1):012072-012072. Available from: https://dx.doi.org/10.1088/1757-899x/1058/1/012072.

28) Muthuraman G. Extractive removal of astacryl blue BG and astacryl golden yellow dyes from aqueous solutions by liquid-liquid extraction. Desalination. 2011;277(1-3):308-312. Available from: https://dx.doi.org/10.1016/j.desal.2011.04.047.

29) Klemz AC, Weschenfelder SE, de Carvalho Neto SL, Damas MSP, Viviani JCT, Mazur LP, et al. Oilfield produced water treatment by liquid-liquid extraction: A review. Journal of Petroleum Science and Engineering. 2021;199:108282-108282. Available from: https://dx.doi.org/10.1016/j.petrol.2020. 108282.

30) Sivamani S, Cuento A, Kashoob A, Al-Hakmaini T. Experimental studies and design of liquid-liquid extraction column for separation of propionic acid from its aqueous solution using organic solvents. 2020. Available from: https://www.researchgate.net/publication/342690157_Experimental_Studies_ and_Design_of_Liquid-Liquid_Extraction_Column_for_Separation_of_Propionic_Acid_from_its_Aqueous_Solution_using_Organic_Solvents.

31) Mendoza SMV, Moreno EA, Fajardo CAG, Medina RF. Liquid-Liquid Continuous Extraction and Fractional Distillation for the Removal of Organic Compounds from the Wastewater of the Oil Industry. Water. 2019;11(7):1452-1452. Available from: https://dx.doi.org/10.3390/w11071452.

32) Ádám Golcs, Bezúr L, Huszthy P, Tóth T. Liquid-liquid extraction and facilitated membrane transport of Pb2+ using a lipophilic acridono-crown ether as carrier. Journal of Inclusion Phenomena and Macrocyclic Chemistry. 2021;99(1-2):117-129. Available from: https://dx.doi.org/10.1007/s10847-02001036-4.

33) Valley B, Jing B, Ferreira M, Zhu Y. Rapid and Efficient Coacervate Extraction of Cationic Industrial Dyes from Wastewater. ACS Applied Materials \& Interfaces. 2019;11(7):7472-7478. Available from: https://dx.doi.org/10.1021/acsami.8b21674.

34) Ferreira AM, Coutinho JAP, Fernandes AM, Freire MG. Complete removal of textile dyes from aqueous media using ionic-liquid-based aqueous two-phase systems. Separation and Purification Technology. 2014;128:58-66. Available from: https://dx.doi.org/10.1016/j.seppur.2014.02.036.

35) Othman N, Aziz NSNM, Harruddin N. Reactive Dye Removal from Simulated Wastewater using Tetrabutyl Ammonium Bromide as an Extractant. Jurnal Teknologi. 2014;67(2):67-67. Available from: https://dx.doi.org/10.11113/jt.v67.2736.

36) El-Ashtoukhy ESZ, Fouad YO. Liquid-liquid extraction of methylene blue dye from aqueous solutions using sodium dodecylbenzenesulfonate as an extractant. Alexandria Engineering Journal. 2015;54(1):77-81. Available from: https://dx.doi.org/10.1016/j.aej.2014.11.007.

37) Soniya M, Muthuraman G. Comparative study between liquid-liquid extraction and bulk liquid membrane for the removal and recovery of methylene blue from wastewater. Journal of Industrial and Engineering Chemistry. 2015;30:266-273. Available from: https://dx.doi.org/10.1016/j.jiec.2015.05.032.

38) Soniya M, Muthuraman G. Recovery of methylene blue from aqueous solution by liquid-liquid extraction. Desalination and Water Treatment. 2015;53(9):2501-2509. Available from: https://doi.org/10.1080/19443994.2013.866055.

39) Elumalai S, Muthuraman G. Removal and Recovery of Methyl Violet Dye from Industrial Wastewater by Liquid-Liquid Extraction. In: Singh V, Yadav S, Yadava R, editors. Water Quality Management. Water Science and Technology Library;vol. 79. Springer Singapore. 2018;p. 231-240. Available from: https://doi.org/10.1007/978-981-10-5795-3_19.

40) Muthuraman G, Teng TT, Tan SH. Liquid-liquid extraction of Cibacron Red FN-R by TBAB as an extractant. Desalination. 2012;284:135-141. Available from: https://dx.doi.org/10.1016/j.desal.2011.08.047.

41) Muthuraman G. Extractive removal of astacryl blue BG and astacryl golden yellow dyes from aqueous solutions by liquid-liquid extraction. Desalination. 2011;277(1-3):308-312. Available from: https://dx.doi.org/10.1016/j.desal.2011.04.047.

42) Muthuraman G, Palanivelu K. Selective extraction and separation of textile anionic dyes from aqueous solution by tetrabutyl ammonium bromide. Dyes and Pigments. 2005;64(3):251-257. Available from: https://dx.doi.org/10.1016/j.dyepig.2004.05.014.

43) Muthuraman G, Teng TT. Solvent extraction of methyl violet with salicylic acid from aqueous acidic solutions. Desalination. 2010;263(1-3):113-117. Available from: https://dx.doi.org/10.1016/j.desal.2010.06.046.

44) Muthuraman G, Teng TT, Leh CP, Norli I. Extraction and recovery of methylene blue from industrial wastewater using benzoic acid as an extractant. Journal of Hazardous Materials. 2009;163(1):363-369. Available from: https://dx.doi.org/10.1016/j.jhazmat.2008.06.122.

45) Muthuraman G, Palanivelu K. Transport of textile dye in vegetable oils based supported liquid membrane. Dyes and Pigments. 2006;70(2):99-104. Available from: https://dx.doi.org/10.1016/j.dyepig.2005.05.002.

46) Muthuraman G, Palanivelu K. Removal and recovery of low salt dye golden yellow LS by liquid-liquid extraction. Indian Journal of Chemical Technology. 2004;11(2):166-169. Available from: http://nopr.niscair.res.in/bitstream/123456789/16773/1/IJCT\%2011\%282\%29\%20166-169.pdf.

47) Othman N, Mili N, Wong YM. Liquid-liquid Extraction of Black B Dye from Liquid Waste Solution Using Tridodecylamine. Journal of Environmental Science and Technology. 2011;4(3):324-331. Available from: https://dx.doi.org/10.3923/jest.2011.324.331.

48) Tuteja R, Sharma JK. Studies on the recovery and re-use of triazine reactive dyes from textile effluent. Rasayan J Chem. 2009;2(2):464-471. Available from: http://www.rasayanjournal.co.in/vol-2/issue-2/39.pdf.

49) Elumalai S, Muthuraman G, Sathya M, Soniya M, Teng TT. Recovery of dye from textile effluents using phenol as an extractant. Journal of Industrial and Engineering Chemistry. 2014;20(4):1958-1964. Available from: https://dx.doi.org/10.1016/j.jiec.2013.09.017. 
50) Xu J, Duan W, Zhou X, Zhou J. Extraction of phenol in wastewater with annular centrifugal contactors. Journal of Hazardous Materials. 2006;131(1-3):98102. Available from: https://dx.doi.org/10.1016/j.jhazmat.2005.09.011.

51) Hu H, Yang M, Dang J. Treatment of strong acid dye wastewater by solvent extraction. Separation and Purification Technology. 2005;42(2):129-136. Available from: https://dx.doi.org/10.1016/j.seppur.2004.07.002.

52) Vijayaraghavan R, Vedaraman N, Surianarayanan M, MacFarlane DR. Extraction and recovery of azo dyes into an ionic liquid. Talanta. 2006;69(5):10591062. Available from: https://dx.doi.org/10.1016/j.talanta.2005.12.042.

53) Raghavarao KSMS, Ranganathan TV, Srinivas ND, Barhate RS. Aqueous two phase extraction?an environmentally benign technique. Clean Technologies and Environmental Policy. 2003;5:136-141. Available from: https://dx.doi.org/10.1007/s10098-003-0193-z.

54) Al-Degs YS, Abu-Surrah AS, Ibrahim KA. Preparation of highly selective solid-phase extractants for Cibacron reactive dyes using molecularly imprinted polymers. Analytical and Bioanalytical Chemistry. 2009;393(3):1055-1062. Available from: https://dx.doi.org/10.1007/s00216-008-2502-1.

55) Chen HL, Wei GT. The Use Ionic Liquid as the Eluent Additive for HPLC Separation of Ionic Dyes. Journal of the Chinese Chemical Society. 2010;57(4B):836-843. Available from: https://dx.doi.org/10.1002/jccs.201000116.

56) Sonune A, Ghate R. Developments in wastewater treatment methods. Desalination. 2004;167:55-63. Available from: https://dx.doi.org/10.1016/j.desal. 2004.06.113.

57) Sivarajasekar N, Ramasubbu S, Maran JP, Priya B. Cationic Dyes Sequestration from Aqueous Phase Using Biosurfactant Based Reverse Micelles. In: Recent Advances in Chemical Engineering. Springer Singapore. 2016;p. 67-74. Available from: https://doi.org/10.1007/978-981-10-1633-2_8.

58) Subashini R, Sivarajasekar N, Balasubramani K, Prakashmaran J. Saponin-Aided Reverse Micellar Extraction of Malachite Green Dye From Aqueous Solutions. In: Lecture Notes on Multidisciplinary Industrial Engineering. Springer Singapore. 2020;p. 89-97. Available from: https://doi.org/10.1007/ 978-981-13-9213-9_9.

59) Sawada K, Ueda M. Enzyme processing of textiles in reverse micellar solution. Journal of Biotechnology. 2001;89(2-3):263-269. Available from: https://dx.doi.org/10.1016/s0168-1656(01)00310-8.

60) Sowmya R, Sivarajasekar N, Manimaran DR, Sivamani S. Biosurfactant assisted liquid-membrane extraction of methyl-orange from aqueous solutions. AIP Conference Proceedings. 2020;2270:20008-20008. Available from: https://doi.org/10.1063/5.0019525.

61) Tang AYL, Lee CH, Wang YM, Kan CW. Reverse Micellar Dyeing of Cotton Fiber with Reactive Dyes: A Study of the Effect of Water pH and Hardness. ACS Omega. 2019;4(7):11808-11814. Available from: https://dx.doi.org/10.1021/acsomega.9b00597.

62) Wang Y, lun Tang Y, hao Lee C, wai Kan C. Reverse Micellar Dyeing of Wool Fabric with Reactive Dyes. Fibers and Polymers. 2019;20(11):2367-2375. Available from: https://dx.doi.org/10.1007/s12221-019-9423-9.

63) Yi S, Sun S, Dai F. Removal, Separation, and Recovery of Mixed Ionic Dyes by Solvent Extraction Using Reverse Micellar Systems. Chemistry Letters. 2015;44(9):1173-1175. Available from: https://dx.doi.org/10.1246/cl.150398.

64) Bukman L, Fernandes-Machado NRC, Caetano W, Tessaro AL, Hioka N. Treatment of wastewater contaminated with ionic dyes: Liquid-liquid extraction induced by reversed micelle followed by photodegradation. Separation and Purification Technology. 2017;189:162-169. Available from: https://dx.doi.org/10.1016/j.seppur.2017.08.004.

65) Ueda AC, de Oliveira LH, Hioka N, Aznar M. Liquid-Liquid Extraction of Basic Yellow 28, Basic Blue 41, and Basic Red 46 Dyes from Aqueous Solutions with Reverse Micelles. Journal of Chemical \& Engineering Data. 2011;56(3):652-657. Available from: https://dx.doi.org/10.1021/je1008558.

66) Pandit P, Basu S. Dye and Solvent Recovery in Solvent Extraction Using Reverse Micelles for the Removal of Ionic Dyes. Industrial \& Engineering Chemistry Research. 2004;43(24):7861-7864. Available from: https://dx.doi.org/10.1021/ie0402160.

67) Pandit P, Basu S. Removal of Ionic Dyes from Water by Solvent Extraction Using Reverse Micelles. Environmental Science \& Technology. 2004;38(8):24352442. Available from: https://dx.doi.org/10.1021/es030573m.

68) Noritomi H, Tamai S, Saito H, Kato S. Extraction of water miscible organic dyes by reverse micelles of alkyl glucosides. Colloid and Polymer Science. 2009;287(4):455-459. Available from: https://dx.doi.org/10.1007/s00396-008-1988-6.

69) Feitosa E, Catelam KT, Hasmann FA, Johansson HO, Roberto IC, Pessoa A. Phase diagrams of a CTAB/organic solvent/buffer system applied to extraction of enzymes by reverse micelles. Journal of Chromatography B. 2008;862(1-2):58-63. Available from: https://dx.doi.org/10.1016/j.jchromb.2007.10.046.

70) Bader NR, Edbey K, Telgheder U. Cloud point extraction as a sample preparation technique for trace element analysis: An overview. Journal of Chemical and Pharmaceutical Research. 2014;6(2):496-501. Available from: https://www.jocpr.com/articles/cloud-point-extraction-as-a-sample-preparationtechnique-for-trace-element-analysis-an-overview.pdf.

71) Noorashikin MS, Sohaimi NM, Suda N, Aziz HZ, Zaini SRM, Kandasamy S, et al. The application of cloud point extraction in environmental analysis. Journal of Sustainability Science and Management. 2017;12(1):79-95. Available from: https://soe.umt.edu.my/wp-content/uploads/sites/51/2017/06/9web.pdf.

72) Purkait MK, Vijay SS, DasGupta S, De S. Separation of congo red by surfactant mediated cloud point extraction. Dyes and Pigments. 2004;63(2):151-159. Available from: https://dx.doi.org/10.1016/j.dyepig.2004.01.010.

73) Duran C, Ozdes D, Bulut VN, Tufekcī M, Soylak M. Cloud-Point Extraction of Rhodamine 6G by Using Triton X-100 as the Non-Ionic Surfactant. Journal of AOAC International. 2011;94(1):286-292. Available from: https://dx.doi.org/10.1093/jaoac/94.1.286.

74) Arunagiri A, Kalaichelvi P, Cherukuri S, Vijayan A. Studies on removal of reactive blue dye using cloud point extraction. International journal of chemical \& environmental engineering. 2012;3(1):16-23. Available from: https://www.researchgate.net/publication/285135842_Studies_on_removal_of_Reactive_ Blue_dye_using_cloud_point_extraction.

75) Mazzola PG, Lopes AM, Hasmann FA, Jozala AF, Penna TC, Magalhaes PO, et al. Liquid-liquid extraction of biomolecules: an overview and update of the main techniques. Journal of Chemical Technology \& Biotechnology. 2008;83(2):143-157. Available from: https://dx.doi.org/10.1002/jctb.1794.

76) Pourreza N, Elhami SH. Removal of malachite green from water samples by cloud point extraction using Triton X-100 as non-ionic surfactant. Environmental Chemistry Letters. 2010;8(1):53-57. Available from: http://dx.doi.org/10.1007/s10311-008-0190-x.

77) Purkait MK, DasGupta S, De S. Determination of thermodynamic parameters for the cloud point extraction of different dyes using TX-100 and TX-114. Desalination. 2009;244(1-3):130-138. Available from: https://dx.doi.org/10.1016/j.desal.2008.04.042.

78) Kamiński W, Kwapiński W. Applicability of liquid membranes in environmental protection. Polish Journal of environmental studies. 2000;9(1):37-43. Available from: http://www.pjoes.com/Applicability-of-Liquid-Membranes-in-Environmental-Protection, 87274,0,2.html.

79) Muthuraman G, Palanivelu K, Teng TT. Transport of cationic dye by supported liquid membrane using D2EHPA as the carrier. Coloration Technology. 2010;126(2):97-102. Available from: https://dx.doi.org/10.1111/j.1478-4408.2010.00233.x.

80) Memon FN, Memon S, Minhas FT. Rapid transfer of methyl red using calix[6]arene as a carrier in a bulk liquid membrane. Comptes Rendus Chimie. 2014;17(6):577-585. Available from: https://dx.doi.org/10.1016/j.crci.2013.09.015. 
81) Montero GA, Smith CB, Hendrix WA, Butcher DL. Supercritical Fluid Technology in Textile Processing: An Overview. Industrial \& Engineering Chemistry Research. 2000;39(12):4806-4812. Available from: https://dx.doi.org/10.1021/ie0002475.

82) Santos WLF, Porto MF, Muniz EC, Povh NP, Rubira AF. Incorporation of disperse dye in N,N-dimethylacrylamide modified poly(ethylene terephthalate) fibers with supercritical CO2. The Journal of Supercritical Fluids. 2001;19(2):177-185. Available from: https://dx.doi.org/10.1016/s0896-8446(00)00083-8.

83) Abbasi A, Seifollahi Z, Rahbar-Kelishami A. Experimental work on decontamination of wastewaters containing organic dye by liquid phase micro extraction method. Separation Science and Technology. 2021;56(6):1047-1059. Available from: https://dx.doi.org/10.1080/01496395.2020.1751201.

84) Kaur P, Rajani N, Kumawat P, Singh N, Kushwaha JP. Performance and mechanism of dye extraction from aqueous solution using synthesized deep eutectic solvents. Colloids and Surfaces A: Physicochemical and Engineering Aspects. 2018;539:85-91. Available from: https://dx.doi.org/10.1016/j.colsurfa. 2017.12.013.

85) Gharehbaghi M, Shemirani F. A Novel Method for Dye Removal: Ionic Liquid-Based Dispersive Liquid-Liquid Extraction (IL-DLLE). CLEAN - Soil, Air, Water. 2012;40(3):290-297. Available from: https://dx.doi.org/10.1002/clen.201100258.

86) Kralj JG, Schmidt MA, Jensen KF. Surfactant-enhanced liquid-liquid extraction in microfluidic channels with inline electric-field enhanced coalescence. Lab on a Chip. 2005;5(5):531-531. Available from: https://dx.doi.org/10.1039/b418815b.

87) Mahmoud AS, Ghaly AE, Brooks MS. Removal of Dye from Textile Wastewater Using Plant Oils Under Different pH and Temperature Conditions. American Journal of Environmental Sciences. 2007;3(4):205-218. Available from: https://dx.doi.org/10.3844/ajessp.2007.205.218. 